Article

\title{
Effect of Gate Selection on the Non-Cohesive Sedimentation in Irrigation Schemes
}

\author{
Shaimaa Theol ${ }^{1, *}$, Bert Jagers ${ }^{2}{ }^{-}$, Jigyasha Rai Yangkhurung ${ }^{3}$, F. X. Suryadi ${ }^{1}$ \\ and Charlotte de Fraiture 1,4 \\ 1 Land and Water Development for Food Security, Water Science Engineering, IHE Delft Institute for Water \\ Education, 2611 AX Delft, The Netherlands; f.suryadi@un-ihe.org (F.X.S.); \\ c.defraiture@un-ihe.org or charlotte.defraiture@wur.nl (C.d.F.) \\ 2 Applied Morphodynamics, Marine and Coastal Systems, Deltares, 2629 HV Delft, The Netherlands; \\ Bert.Jagers@deltares.nl \\ 3 Department of Irrigation, Ministry of Energy, Water Resources and Irrigation, 44600 Singhdurbar, \\ Kathmandu, Nepal; j.rai@un-ihe.org \\ 4 Department of Environmental Sciences, Water Resources Management, \\ Wageningen University and Research, 6708 PB Wageningen, The Netherlands \\ * Correspondence: s.theol@un-ihe.org or sh_amier@yahoo.com
}

Received: 29 July 2020; Accepted: 1 October 2020; Published: 4 October 2020 updates

\begin{abstract}
In order to cover the crop water requirements, flow control structures such as gates and weirs are used to transfer the desired amount of water from the canals to the field canals. This paper examines the impact of gate operation and the selection of gates on the deposition of non-cohesive sediment. The Delft3D model is used to simulate the effects of different scenarios regarding gate operation and the location of the gate that is opened. The model results showed that the gate selection affects not only hydraulic parameters but also morphological parameters. It was found that opening the gates closer to the offtake resulted in less sediment deposition at the entrance of the branch canal when compared to opening the gates further away. Gate selection can be used as a tool in sediment management. By alternating the opening of different gates sediments that are already deposited after opening one gate can be eroded when another gate is operated, thus minimizing the additional cost of sediment removal. The use of Delft3D proved beneficial as the selection of different gates leads to asymmetric sediment deposition patterns which would be missed when using a 1D model.
\end{abstract}

Keywords: non-cohesive sediment deposition and erosion; sediment transport; gate operation; gate selection; Delft3D model

\section{Introduction}

\subsection{Background}

Water flows in irrigation canals tend to change depending on the amount of water demanded by crops or the supply of water in the irrigation system. This change in flow is assured by the operation of flow control structures such as gates and weirs. Canal operation results in unsteadiness of flow which is contrasting the steady and gradually uniform flow as is typically assumed in canal design [1]. A minor variation in the flow characteristics may result in a major effect in the sediment transport patterns, leading to erosion and/or sediment deposition in canals and around hydraulic structures in case of sediment-laden water. To keep a canal sediment-free, the sediment transport capacity of the canal should be maintained as foreseen in the design criteria. However, heavy sediment load, badly designed canals and poor canal operation and management may result in undesirable erosion and sediment deposition. Deposition of sediment causes raising the bed levels which leads to disrupt 
the water distribution by raising the water level in the upstream part of the canal and lowering water level in downstream of the canals. This will lead to unfair water allocation; upstream outlets will get more water than their quota and downstream outlets will get less water.

Canal operation is a crucial issue in sediment transport in irrigation systems, with gates being opened in varying heights and duration [2,3]. This paper investigates how different gate operation scenarios can be used for minimizing undesirable sedimentation in irrigation canals, especially in the vicinity of flow control structures.

\subsection{Previous Studies}

Sediment transport affects the hydrodynamic patterns, and a study was carried by Dal Sasso et al. [4] to illustrate the impact of landslides and debris flows on the river network and its mass transport processes, and how they determine the modifications of the river pattern with consequent effects on the hydrodynamic phenomena, alterations of the existing morphologies and possible interferences with anthropic works. They found that the modifications of the cross-section geometry and channel slope may produce changes in the sediment budget, with consequent repercussions on the stream evolutionary dynamics and its equilibrium configuration, leading to a new river branch arrangement. Different studies regarding sediment transport in irrigation canals showed the relationship between sediment problems and canal operation and management. A review carried by Shimizu [5] of recent advances in computational morphodynamics modeling of coupled flow-bed-sediment systems for 10 applications, where each of these applications is drawn from solvers included in the public domain International River Interface Cooperative (iRIC) software package. Shimizu [5] believe that the continued development of scientific interaction among morphologists and a similar commitment to sharing computational code and interface tools, as exemplified by the iRIC project, are both fundamental parts of the continued development of this field.

Depeweg et al. [6] by employing different scenarios of canal operation, show that sediment problems in the Sunsari Morang Irrigation System in Nepal could be avoided or minimized by adapting gate operation plans. This finding was later confirmed by Paudel [7]. Observations by Munir [3] confirmed that hydraulic efficiencies of canals that are operated based on the supply had not been affected by the sediment transport. Sediment depositions accumulated when canals that run with low discharge can be flushed away during times of peak flow by regulating the operation (Munir [3]). To reduce the deposition on high concentrated sediment periods, Munir [3] recommended operating the canals in a supply-based operation. From these studies, it is clear that canal operation and the operating method have an effect on sediment transport. Theol et al. [8] found that proper location of weirs and proper adjusting of the branch canal's gate can substantially reduce sedimentation problems while ensuring sufficient water delivery to crops.

Previous studies were done using 1D models which simulate the patterns of the sediment erosion and deposition in the longitudinal direction of the canal, assuming that the sediments are distributed just like water in the longitudinal direction. However, because of unsteady and variable flow due to canal operation, sediment depositions are unequally distributed, especially near off-takes and structures. The effect of unequal distribution might be neglected when using $1 \mathrm{D}$ models. To better represent the sedimentation patterns along and across irrigation canals, 2D or even 3D models are needed [9].

Many numerical shallow water models have been developed for the analysis of sediment behavior in rivers, estuaries and lakes; some support only depth averaged (2D) mode, such as: MIKE21C [10], BASEMENT [11] and XBeach [12], whereas other can be run in both 2D and 3D mode, such as Telemac [13] and Delft3D [14,15]. Far fewer models were developed for simulating sediments in irrigation systems and most of them are limited because of being $1 \mathrm{D}$ and considering sediment transport in the equilibrium condition only, while very few use a 3D model. In this research, the well-established Delft3D model was selected because it can be run in both 2D and 3D mode both for the hydrodynamics as well as for the suspended load transport. 
The other benefit of Delft3D is its ability to simulate the operation of gates with real-time control to show the morphological changes in canal beds. This paper uses the Delft3D model to analyze the impact of gate selection on the deposition and distribution within the cross section of non-cohesive sediment in the Sunsari Morang Irrigation system in Nepal; it builds on earlier work by Yangkhurung [16] and Paudel [7].

\section{Materials and Methods}

\subsection{Data}

The main canal and Sukhasaina secondary canal (S1) of the Sunsari Morang Irrigation System (SMIS) were selected for this study (Figure 1), as this is the first major branch canal that includes proper water regulating structures. The S1 has its offtake at chainage $9.4 \mathrm{~km}$ of the main canal and irrigates about 8146 ha with a discharge of $5.7 \mathrm{~m}^{3} / \mathrm{s}$ [17]. The authors took the canal layout from Google Earth, while the canal geometry was taken from various documents and later verified with the staff of SMIS (Table 1).

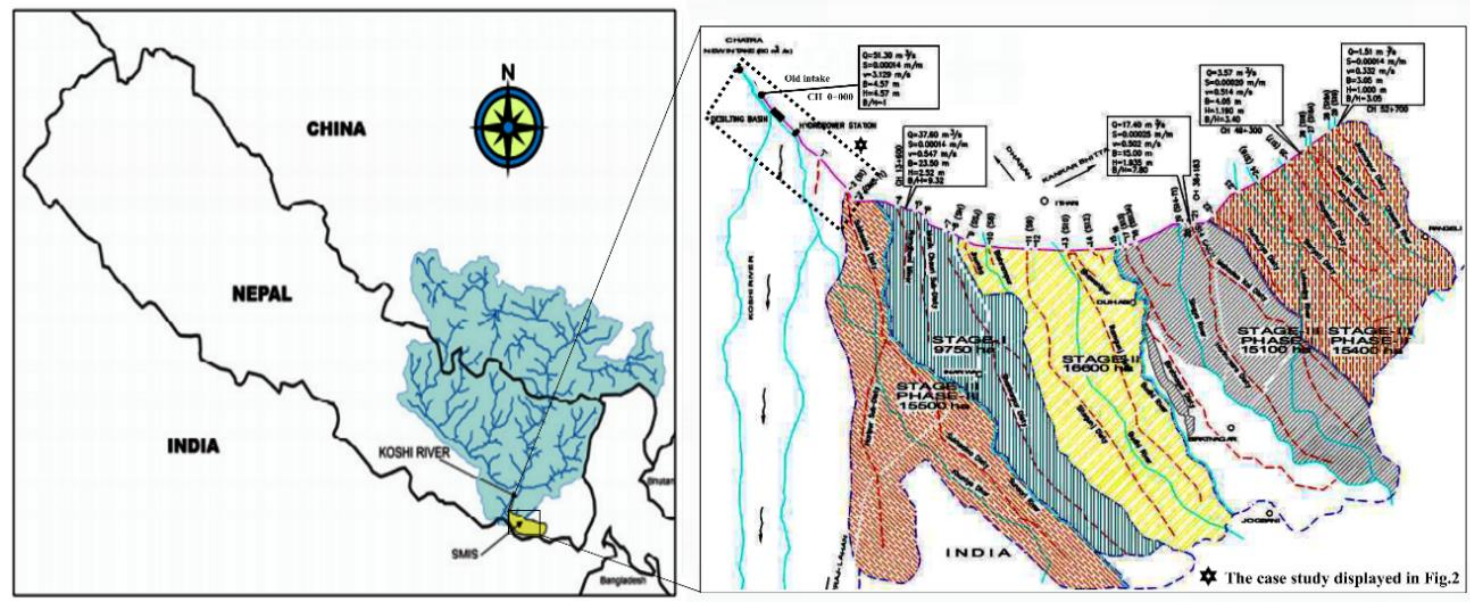

Figure 1. Location and layout of the Sunsari Morang Irrigation System (SMIS) [18].

Table 1. Canal Geometry of the study area.

\begin{tabular}{ccc}
\hline & Main Canal & Branch Canal \\
\hline Bed Width, $b(\mathrm{~m})$ & 18 & 6 \\
Canal Depth, $H(\mathrm{~m})$ & 6 & 4 \\
Side Slope, $z$ & 1.5 & 1.5 \\
Canal Slope, $S$ & 0.00014 & 0.00014 \\
\hline
\end{tabular}

\subsubsection{Bathymetry}

The main characteristics of the main and the branch canals as the canal geometry are listed in Table 1 . These data are the most important to estimate the discharge and to know the canal capacity.

\subsubsection{Roughness}

According to Chow [19], the Manning's roughness (n) for an earthen canal, meandered with grass and some weeds is estimated at $0.03 \mathrm{~s} / \mathrm{m}^{1 / 3}$. This characterization is close to the existing canals in the system, and therefore the value of $n$ for the main canal is taken as $0.03 \mathrm{~s} / \mathrm{m}^{1 / 3}$.

\subsubsection{Sediment Data}

The sediments entering SMIS are mostly fine sediments with median diameter $\left(\mathrm{d}_{50}\right)$ of less than $200 \mu \mathrm{m}$ [7]. The median diameter of $100 \mu \mathrm{m}$ is used for representing the sediment size of the Sitagunj 
canal (S9) of SMIS by Paudel [7] which is downstream of S1. For this reason, the median diameter of $100 \mu \mathrm{m}$ is used to represent sediment size of the $\mathrm{S} 1$ canal, with a specific density of $2650 \mathrm{~kg} / \mathrm{m}^{3}$.

The concentration of sediment in the river changes according to the time of year. In the winter, the concentration is less than $0.2 \mathrm{~g} / \mathrm{L}$, while in monsoon season the concentrations are peaking to more than $3 \mathrm{~g} / \mathrm{L}$.

The gate just after the pre-settling basin is closed if the sediment concentration exceeds $0.3 \mathrm{~g} / \mathrm{L}$ [7]. Therefore, the sediment concentration of $0.3 \mathrm{~g} / \mathrm{L}$ with a median diameter of $100 \mu \mathrm{m}$ is selected for the simulation.

\subsubsection{Gates}

For most offtakes, the water levels at CMC are usually controlled by cross regulators, while in the branch canal this is done by manually operated vertical steel gates $[17,20]$. The cross regulator $(\mathrm{CR})$ in the main canal consists of a total of eight gates with 4 gate panels, each of $1.5 \mathrm{~m}$ wide in 2 bays. The head regulator (HR) is similar but has 4 gates and 2 gate panels. For simplicity, 4 gates and 2 gates are considered in the simulation for CR and HR, respectively, each being $3 \mathrm{~m}$ wide.

\subsection{Delft3D Model}

Delft3D model is a multi-dimensional model developed by Deltares [14]. It calculates the non-steady flow and sediment transport phenomena in 2D or 3D mode depending on the model input settings. The sediment component was developed and validated by Lesser et al. [15] The Delft3D model has been chosen for this study in order to (1) represent the effects of gate selection on the non-cohesive sediments behaviour, (2) show the settling basin effect on the deposition of non-cohesive sediments, (3) clarify the non-uniform flows around structures and offtakes, and (4) better simulate longitudinal and cross-sectional deposition patterns. The Delft3D model mostly has been used for rivers [21-23] and for estuaries [24-28]. Recently, the model was also applied for irrigation canals [29]. For the application in this paper the real-time control (RTC) module is used, which permits to change the gate height during the simulating period [14].

\subsubsection{Governing Equations}

Delft3D solves the shallow equations [30,31] either in depth averaged (2D) mode or in a hydrostatic 3D mode using terrain-following $\sigma$-coordinates [32]. These equations are discretized and solved using a cyclic alternating direction implicit method on a curvilinear Arakawa C-grid [33]. Because of the large differences in horizontal and vertical scales typical for environmental applications, the model uses an anisotropic viscosity. For the horizontal direction a constant viscosity was applied, and for the vertical direction (only in 3D mode obviously) the viscosity is derived from a set of $k-\varepsilon$ equations [34]. In 2D mode, secondary flow is included via parametrization [35]. The advection-diffusion equation is solved iteratively using a red-black Jacobi method; the 3D $\sigma$-mode includes a correction for the steep slopes [36]. More details can be found in the Delft3D-FLOW user manual [14].

Concerning the sediment transport, Delft3D follows the approach developed by Van Rijn [37] that splits sediment transport into bedload and suspended load to understand the characterization of the behavior of non-cohesive sediments. A reference height (a) is used to differentiate between these loads; the sediments which move below this reference height are treated as bedload transport and above it as suspended load transport. In the Delft3D model, the layer situated directly above the Van Rijn reference height is called the $\mathrm{kmx}$-layer. The source and sink terms for the interaction of the water column and the bed are located in this layer.

The direction of the bedload transport is in first order equal to the direction of the depth-averaged velocity in a 2D simulation and equal to the direction of the velocity at the reference height (a) in a 3D simulation [38]; secondary flow correction is applied in 2D simulations, and adjustments due to bed slope are applied in both 2D and 3D simulations. Running the model in 2D mode is to ensure better representation of the sediment processes and the large scale behavior with an acceptable simulation 
time period [8]. Running the model in 3D mode (5 layers) provides information about flow and sediment parameters in the vertical direction and gives more details near structures [39]. The results of the 2D and 3D simulations look identical; however, in this paper, the graphs are based on the 3D simulations.

The advection-diffusion equation solves the sink term implicitly, whereas the source term is solved explicitly. The concentration and concentration gradient at the bottom of the kmx-layer needs to be approximated, in order to determine the sink and source terms. A standard Rouse profile between the reference height (a) and the center of the kmx-layer was assumed. Sink and source terms of the kmx-layer are calculated as follows:

$$
C^{l}=C_{a}{ }^{l}\left[\frac{a(h-z)}{z(h-a)}\right]^{A^{1}}
$$

The reference height can be represented as:

$$
\mathrm{a}=\min \left[\max \left(\mathrm{f}^{*} \mathrm{ks}, 0.01 \mathrm{~h}\right), 0.2 \mathrm{~h}\right]
$$

where;
$\mathrm{A}^{\mathrm{l}}$ : Rouse number [-]
a: Van Rijn's reference height [m];
$C^{1}$ : concentration of sediment fraction $1\left[\mathrm{~kg} / \mathrm{m}^{3}\right]$;
$\mathrm{C}_{\mathrm{a}}{ }^{1}$ : reference concentration of sediment fraction $1\left[\mathrm{~kg} / \mathrm{m}^{3}\right]$;
f: user defined proportionality factor [-] (equals to 1);
h: water depth [m];
$\mathrm{k}_{\mathrm{s}}$ : roughness height $[\mathrm{m}]$;
z: elevation above the bed [m].

\section{Erosion formula:}

$$
\mathrm{E}^{(1)}=\frac{\alpha_{2}{ }^{1} \varepsilon_{\mathrm{s}}{ }^{1} C_{\mathrm{a}}^{1}}{\Delta \mathrm{z}}-\frac{\alpha_{2}{ }^{1} \varepsilon_{\mathrm{s}}{ }^{1} C_{\mathrm{kmx}}^{1}}{\Delta \mathrm{z}}
$$

Deposition formula:

$$
\mathrm{D}=\alpha_{1}{ }^{1} \mathrm{C}_{\mathrm{kmx}}^{\mathrm{w}} \mathrm{w}_{\mathrm{s}}{ }^{1}
$$

where:

$\mathrm{C}_{\mathrm{a}}^{1}$ : Reference concentration of sediment fraction $1\left[\mathrm{~kg} / \mathrm{m}^{3}\right]$;

$\mathrm{C}_{\mathrm{kmx}}^{\mathrm{l}}$ : Average concentration of the $\mathrm{kmx}$ cell of sediment fraction $1\left[\mathrm{~kg} / \mathrm{m}^{3}\right]$;

$\mathrm{w}_{\mathrm{s}} \mathrm{l}$ : Settling velocity $[\mathrm{m} / \mathrm{s}]$;

$\Delta \mathrm{z}$ : Difference in elevation between the center of the kmx cell, Van Rijn's reference height: $\Delta \mathrm{z}=\mathrm{z}_{\mathrm{kmx}}-\mathrm{a}[\mathrm{m}] ;$

$\alpha_{1}^{1}$ : First correction factor for sediment concentration [-];

$\alpha_{2}{ }^{1}$ : Second correction factor for sediment concentration [-];

$\varepsilon_{\mathrm{s}}^{1}$ : Sediment diffusion coefficient evaluated at the bottom of the kmx cell of sediment fraction 1 [-].

\subsubsection{Model Setup}

For validation purposes, the grid of this case is built based on the layout and the dimensions of the entire main canal and branch canal, including the settling basin. For the simulations of the scenarios, the results are analyzed zooming into the section around the weir and outlet to the branch canal, excluding the settling basin. The bathymetry is developed based on the canal dimensions, the bed level of a known point, and canal bed slope. The discharge is the upstream boundary condition in the main canal, which is kept constant during the simulation period. The Q-h relationship is the downstream boundary of the main canal. The flow resistance due to a barrier is dependent on the blocked flow by the gate, where the gate prevents the flow located in the top grid cells. Depending on the water 
elevation and the gate level, the number of blocked layers will be specified. The depth-averaged analysis shows that the energy loss coefficient $\left(\mathrm{C}_{\text {loss }}\right)$ depends on the gate contraction, where it becomes zero when the gate is fully open. In the Delft3D model the appropriate energy loss coefficient $\left(C_{\text {loss }}\right)$ for each gate must be specified [14]. However, the energy loss coefficient for the gates is not known; it is assumed to be 0.9 , the default value, for all the gates in the model [16]. The Real-time control tool simulates the gate operation.

The difference between the sediments flowing in and out of the system determines the changes in the canal morphology. This change is computed for each cell using the sediment transport formula of non-cohesive sediments developed by Van Rijn et al. (2000). The method developed by Van Rijn [37] is used to calculate the settling velocity depending on the suspended sediment size [14].

The initial conditions are set as water level of $109 \mathrm{~m}+$ MSL with initial sediment concentration for each type of sediments of $0 \mathrm{~kg} / \mathrm{m}^{3}$. The initial sediment layer in the unlined section of the canal is assumed as $50 \mathrm{~cm}$, whereas in the lined sections and near structures the initial sediment layer is assumed zero since they are considered non-erodible.

The designed discharge is $51.3 \mathrm{~m}^{3} / \mathrm{s}$; however, it is observed that some parts of the canal are often overflowing during canal operation Renault et al. [20], implied that the canal capacity is actually smaller than the design discharge. For this reason, a smaller discharge is used to avoid overflowing [17]. A discharge of $30 \mathrm{~m}^{3} / \mathrm{s}$ is assumed.

The upstream boundary condition is the constant discharge of $30 \mathrm{~m}^{3} / \mathrm{s}$ with a sediment concentration of $0.3 \mathrm{~kg} / \mathrm{m}^{3}$. The discharge, sediment particle size and concentration are kept constant throughout the simulation. The Q-h relationship based on the canal geometry is taken as a downstream boundary condition at the end of the main canal as the inflow is changing due to the water extraction at the outlets. At the end of the branch canal the boundary condition is the water level, fixed at $104.97 \mathrm{~m}$, because the branch canal is flowing into paddy rice fields with a wide undefined outflow.

\subsection{Study Area}

One of the biggest schemes in Nepal is the Sunsari Morang Irrigation System (SMIS), which was constructed by the Government of India under the bilateral agreement between Nepal and India in 1954 and was handed over to Nepal only after two years of trial operation [40]. The project aimed to irrigate 68,000 ha of Sunsari and Morang districts of the Eastern Terai region of Nepal [16]. The Koshi River is the source of this system (Figure 1). Figure 1 shows the location of the SMIS and its layout; the Koshi River is highly sediment loaded [7]. Figure 2 displays the schematization of the case study. The average monthly flow carried by the river ranges between 500 and $6000 \mathrm{~m}^{3} / \mathrm{s}$ while the annual flood discharge reaches $7000 \mathrm{~m}^{3} / \mathrm{s}$ [41]. Various measures such as a pre-settling basin (Figure 1; Figure 2) with a flushing arrangement and desilting basin with two dredgers have been applied to diminish the sediment problem in the system [7].

Though the sediment problem has been reduced, the undesirable erosion and deposition are still evident from the raised canal bed, as well as clogged structures and the high investment requirements to remove sediment from the system. This may be because, during the design of the system, the selected silt factor was small or the criteria of the sediment transport might have been ignored [7]. Furthermore, the canals in SMIS are unlined which makes the system more vulnerable to sediment-related problems.

Due to the high demand in peak season and low flow in the source during the off-peak season, there was insufficient discharge in the Chatara Main Canal (CMC), leading to deviations in the developed cropping calendar. In order to supply a constant discharge, the canals are operated in rotation. The rotation duration for each canal depends on the water availability in the system. The water availability depends on the sediment concentration and on the river flow, which in turn depends on the rainfall [42]. In addition, most of the canals in the system do not have or follow canal operation plans. Canal and gate operation seem ad hoc and are not documented. Therefore, SMIS was selected for the study because of its vulnerability to the sediment problem and its potential to provide efficient and effective irrigation to a large agricultural area. 


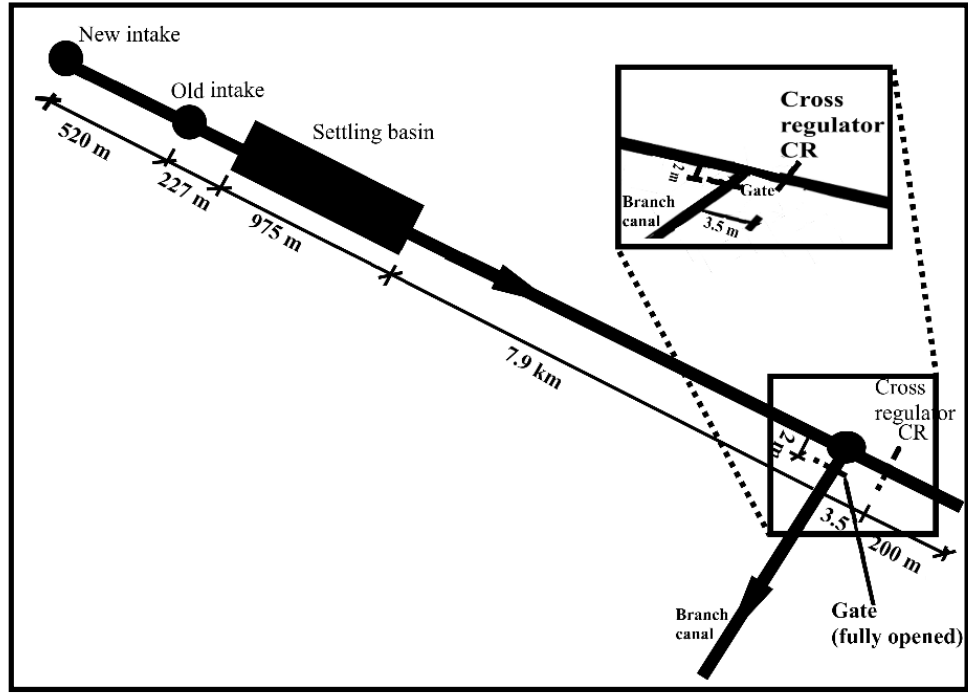

Figure 2. Case study schematization.

\subsection{Validation}

\subsubsection{Hydrodynamic Validation}

In order to validate the model and ensure it provides reasonable hydrodynamic results, the main canal and branch canal have been separated and simulation results have been compared with the boundary conditions for each model. The upstream boundary condition is the constant discharge; the downstream boundary condition for each model is the Q-H relationship. Table 2 compares the calculated and the simulated water heights $(\mathrm{H})$ for a range of discharges $(\mathrm{Q})$ in the main canal at observation point 1 (OP1) and the branch canal in observation point 1 (B-OP1), and these points are shown in Figure 6.

Table 2. Calculated and Simulated water depth for specific discharges for Main and Branch Canal.

\begin{tabular}{|c|c|c|c|c|c|}
\hline \multicolumn{3}{|c|}{ Main Canal } & \multicolumn{3}{|c|}{ Branch Canal } \\
\hline \multirow{2}{*}{$\mathrm{Q}\left[\mathrm{m}^{3} / \mathrm{s}\right]$} & \multirow{2}{*}{$\begin{array}{c}\text { Calculated } H, \\
(\mathrm{~m})\end{array}$} & $\begin{array}{c}\text { Simulated } H, \\
(\mathrm{~m})\end{array}$ & \multirow{2}{*}{$\mathrm{Q}\left[\mathrm{m}^{3} / \mathrm{s}\right]$} & \multirow{2}{*}{$\begin{array}{c}\text { Calculated } H \\
\text { (m) }\end{array}$} & $\begin{array}{c}\text { Simulated H, } \\
(\mathrm{m})\end{array}$ \\
\hline & & By Delft3D & & & By Delft3D \\
\hline 7.2 & 1 & 1 & 2.5 & 1 & 1 \\
\hline 23.3 & 2 & 2 & 5.2 & 1.5 & 1.5 \\
\hline 30 & 2.3 & 2.3 & 6.3 & 1.7 & 1.7 \\
\hline 46.9 & 3 & 3 & 8.7 & 2 & 2 \\
\hline
\end{tabular}

From Table 2, we can see that for the provided boundary conditions the simulated and calculated water depths are equal. Therefore, the hydrodynamics of the main and the branch domain are considered reliable as a basis for the next step in the simulation.

Consequent to the above verification, the main and the branch canals are combined by using the domain decomposition tool and the new combined domain is run. The model results are checked with field data and with the results from another hydrodynamic model, DUFLOW (Table 3). DUFLOW is a 1D program which can simulate unsteady flow. From the field data, for a certain discharge, the gauge reading of one point in CMC is known. The water level at this site was compared with the simulated water level. 
Table 3. Water level obtained from various sources at an observation point.

\begin{tabular}{cccc}
\hline & Flow $\left(\mathbf{m}^{\mathbf{3}} \mathbf{s}\right)$ & $\begin{array}{c}\text { Water Level } \\
\mathbf{( m )}\end{array}$ & $\begin{array}{c}\text { \% Variation from } \\
\text { Design Discharge }\end{array}$ \\
\hline Designed discharge & 51.3 & 2.98 & \\
DUFLOW Model & 51.3 & 2.97 & 0.0064 \\
Delft3D Model & 51.3 & 2.91 & -2.18 \\
\hline
\end{tabular}

The results show that the simulated water levels of both models are comparable. DUFLOW slightly overvalues the water level at the observation point while Delft3D has slightly underrated it. The DUFLOW results seem to be nearer to the actual value than Delft3D's results. However, the known observation point may provide a different value of the water level since DUFLOW does not calculate the water level for a certain point; it calculates it for the whole section. The Delft3D model, on the other hand, calculates the water level at the center of each cell causing a staggered effect which increases the sectional area, resulting in a lower water level. Delft3D considers many parameters that are ignored by DUFLOW, such as the side slopes and roughness. However, the results are both fairly close to the field data as shown in Table 3. It can, therefore, be said that the model is able to satisfactorily mimic the real situation from the hydrodynamic point of view.

\subsubsection{Morphological Validation}

The morphological model was prepared based on the model setup and the actual field conditions.

Compared with real field conditions for the entire main canal including the settling basin to validate the sediment deposition and erosion, the simulation results of the main canal including the settling basin (Figure 2) are compared with real field conditions. The simulation shows how the sediments start to rapidly deposit in the upstream part of the main canal (Figure 3). This increases the bed level and leads to raising the water level upstream the main canal. Some sediments move forward and settle at the beginning of the settling basin raising the bed on the right side. After the settling basin, there is erosion due to the abrupt contraction in the canal.

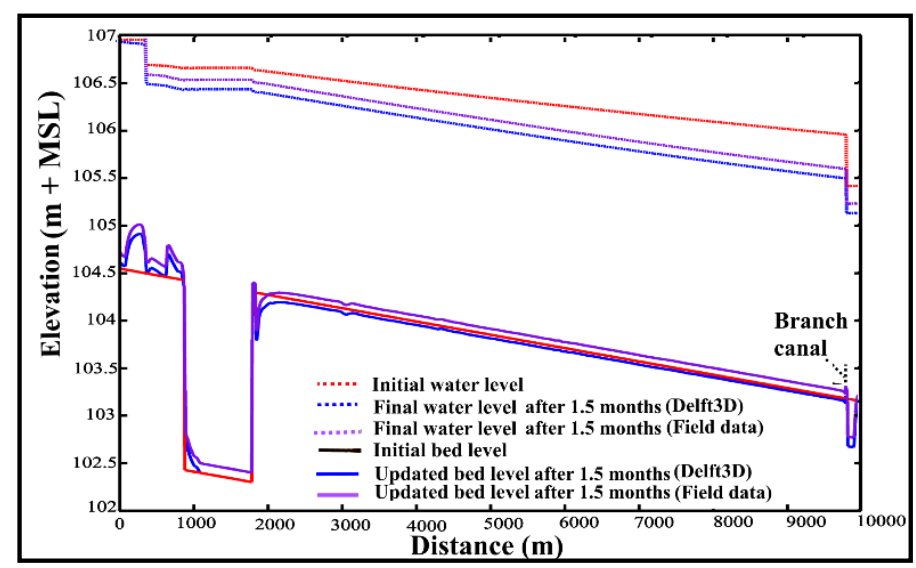

Figure 3. Bed level and water level in the main canal including the settling basin.

The measurement line is along the computational grid line that follows the center lines of the canals and passes through the eastern side of the settling basin.

The velocity is reduced along the main canal especially in the settling basin, where it reaches zero in the right bank, which leads to sediment deposition (Figure 4). After the settling basin, the velocity reaches $0.6 \mathrm{~m} / \mathrm{s}$. 


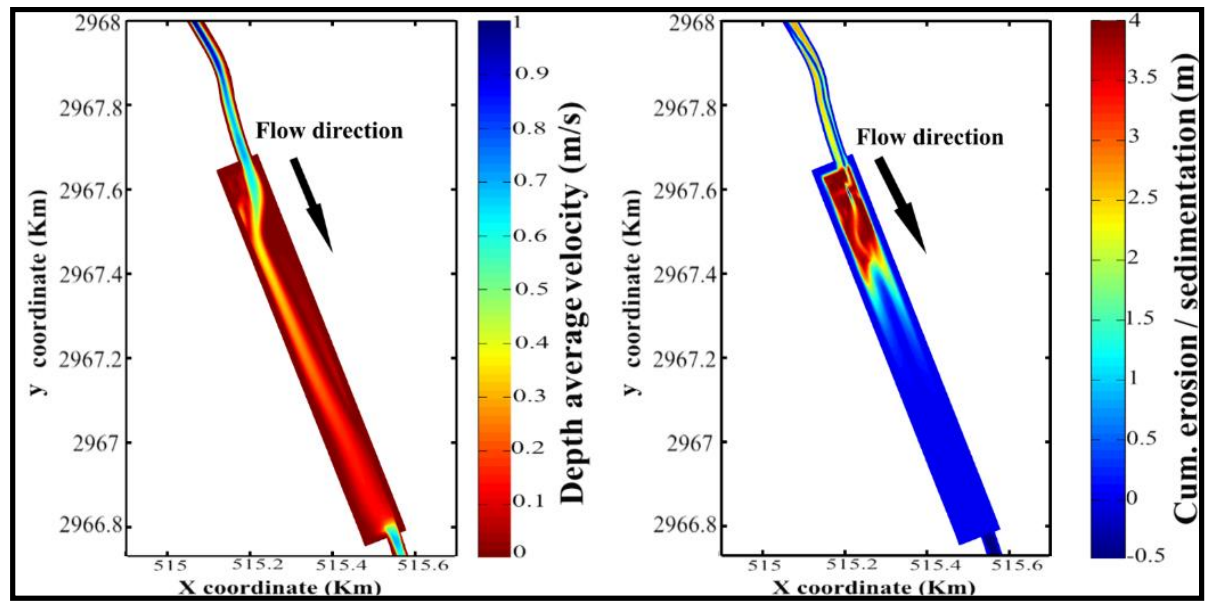

Figure 4. The relationship between velocity and the accumulated sediment in the settling basin.

Figure 4 clearly illustrates how rapidly the deposition of the sediment can affect the water level. Additionally, it displays the role of the settling basin in trapping the non-cohesive sediment. Figure 4 shows the results after one month. Running the same case for a longer period leads to more sediments trapped and accumulated in the settling basin.

Figure 4 presents the relationship between the velocity and the accumulation of sediment. When velocity decreases, sediment deposition occurs. Oppositely, if the velocity increases, deposition is reduced.

Comparing the simulation results with actual situation as captured from Google Earth (Figure 5), shows the similarity of the sedimentation pattern in the settling basin, where the deposition occurs at the right side of the settling basin.
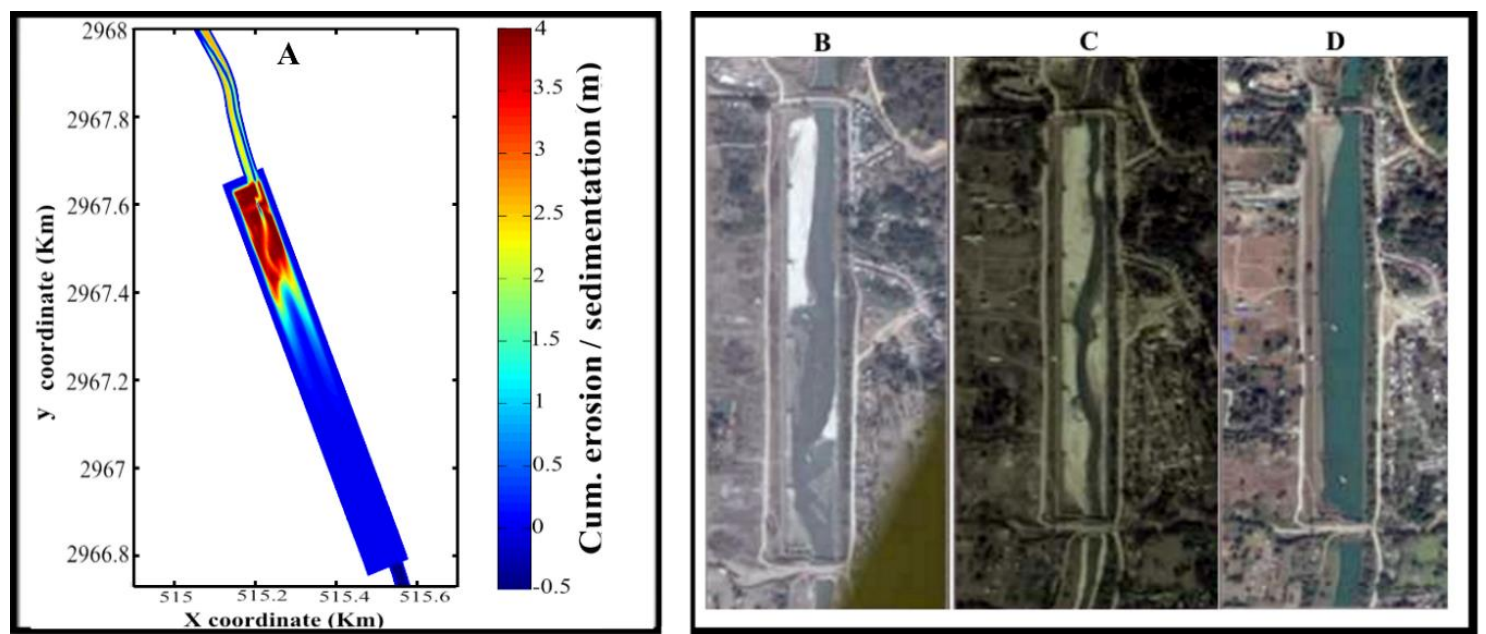

Figure 5. The similarity between Delft3D results and the actual situation captured from Google Earth (A) Delft3D results, (B) the actual case in 2004, (C) the actual case in 2005, (D) the actual case in 2016.

From Figure 5 we can see that Delft3D is able to satisfactorily represent the actual situation from a morphological point of view. The shape of the thalweg, i.e., the planform of the insized channel, is indeed different between the simulation in $5 \mathrm{~A}$ and the observation in $5 \mathrm{C}$. The exact shape and position depends on detailed processes not resolved by the model, but the overall characteristics of the deposits (over the full width of the settling basin with a narrow channel remaining) are captured by the physics in the numerical model. 


\subsection{Scenarios}

Different scenarios are tested using the Real-time Control (RTC) module. The RTC permits changing the status of the gate (opening partially, fully or closing the gate) during the simulation period. All the Cross-Regulator (CR) gates are left fully open for half month, then the gates are fully opened or closed for a month, depending on the scenario (Table 4). Hydraulic input and sediment are maintained constant for all scenarios, changing only the opening of the gate. Scenario names are given as Scenario for Gate Operation (SGO) followed by a number. The analysis focuses on the area within $1.15 \mathrm{~km}$ upstream of the offtake to the downstream end of the main canal (Figure 6), excluding the desilting basin. This is done only for the gates of the Cross-Regulator (CR) while the gates of the Head Regulator are left fully open for all scenarios (Figure 7).

Table 4. Gate operation scenarios.

\begin{tabular}{|c|c|c|c|c|c|c|}
\hline $\begin{array}{l}\text { Simulation } \\
\text { Time }\end{array}$ & & 0.5 Month & & $1 \mathrm{M}$ & & \\
\hline Gates & $\begin{array}{l}\text { Scenario } \\
\text { name }\end{array}$ & & $\begin{array}{c}\text { Gate a } \\
\text { (left bank) }\end{array}$ & $\begin{array}{c}\text { Gate b } \\
\text { (middle left) }\end{array}$ & $\begin{array}{l}\text { Gate c } \\
\text { (middle } \\
\text { right) }\end{array}$ & $\begin{array}{c}\text { Gate d } \\
\text { (right bank) }\end{array}$ \\
\hline $\begin{array}{l}\text { All Gates } \\
\text { Open }\end{array}$ & SGO1 & & Open & Open & Open & Open \\
\hline $\begin{array}{l}\text { Two gates } \\
\text { open }\end{array}$ & $\begin{array}{l}\text { SGO2 (AB) } \\
\text { SGO3 (BC) } \\
\text { SGO4 (CD) } \\
\text { SGO5 (AD) }\end{array}$ & $\begin{array}{l}\text { All gates } \\
\text { open }\end{array}$ & $\begin{array}{l}\text { Open } \\
\text { Closed } \\
\text { Closed } \\
\text { Open }\end{array}$ & $\begin{array}{l}\text { Open } \\
\text { Open } \\
\text { Closed } \\
\text { Closed }\end{array}$ & $\begin{array}{l}\text { Closed } \\
\text { Open } \\
\text { Open } \\
\text { Closed }\end{array}$ & $\begin{array}{l}\text { Closed } \\
\text { Closed } \\
\text { Open } \\
\text { Open }\end{array}$ \\
\hline $\begin{array}{l}\text { One gate } \\
\text { open }\end{array}$ & $\begin{array}{l}\text { SGO6 (A) } \\
\text { SGO7 (B) } \\
\text { SGO8 (C) } \\
\text { DGO9 (D) }\end{array}$ & & $\begin{array}{l}\text { Open } \\
\text { Closed } \\
\text { Closed } \\
\text { Closed }\end{array}$ & $\begin{array}{l}\text { Closed } \\
\text { Open } \\
\text { Closed } \\
\text { Closed }\end{array}$ & $\begin{array}{c}\text { Closed } \\
\text { Closed } \\
\text { Open } \\
\text { Closed }\end{array}$ & $\begin{array}{l}\text { Closed } \\
\text { Closed } \\
\text { Closed } \\
\text { Open }\end{array}$ \\
\hline
\end{tabular}

Additional scenarios covering the multiple operations of different gates at the same time are included in the Supplementary Materials.

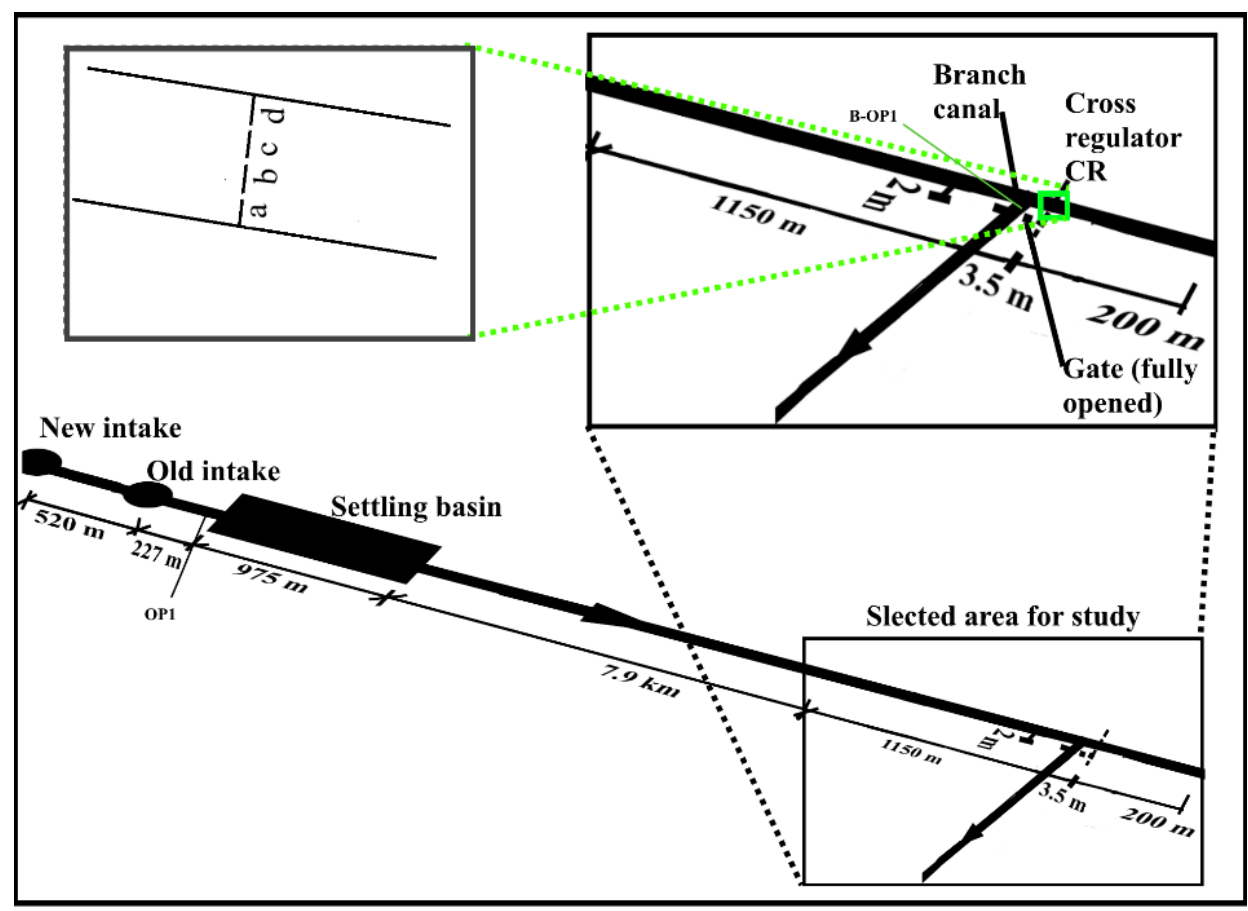

Figure 6. The selected area. 


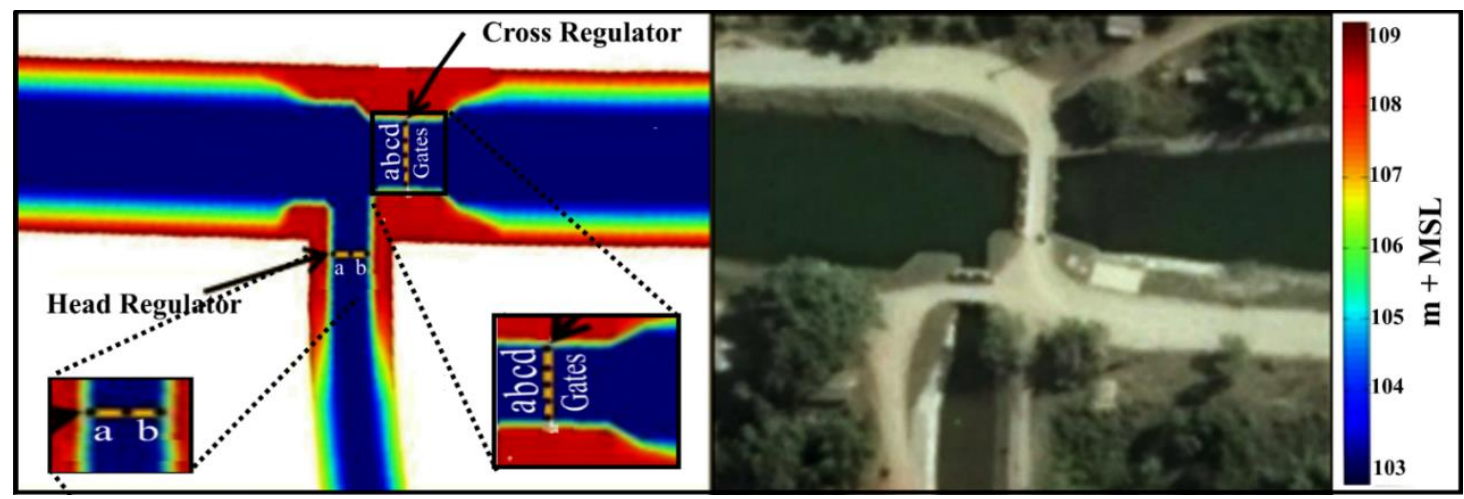

Figure 7. The location of Gates in the Canals in the model (left) and as seen in Google Earth (right).

\section{Results}

\subsection{Scenario 1 Reference Case (SGO1) all Gates Open}

For the reference case and the following scenarios, after excluding the settling basin as shown in Figure 6, the model simulates a duration of 1.5 months. From $\mathrm{Km} 0$ to $\mathrm{Km} \mathrm{1.15,} \mathrm{sediments} \mathrm{start} \mathrm{to}$ deposit rapidly upstream and increase with time. This increase in the bed level again leads to raising the water level upstream of the main canal. Sediments move forward along the main canal due to the sufficient velocity and transport capacity to convey the sediments. The deposition of the sediments in $\mathrm{km} 1.15$ is less than the upstream location, where it reaches $0.4 \mathrm{~m}$. After $\mathrm{Km} 1.15$, the deposition increases as in this vicinity the water is diverted to the branch canal. Less water leads to less velocity, hence an increase in deposition. After the diversion to the branch canal, there is a contraction in the main canal, leading to increased velocity and reduced deposition in that location, and thereafter more deposition upstream the gates. Unlike the previous case, there is no erosion (Figure 8).

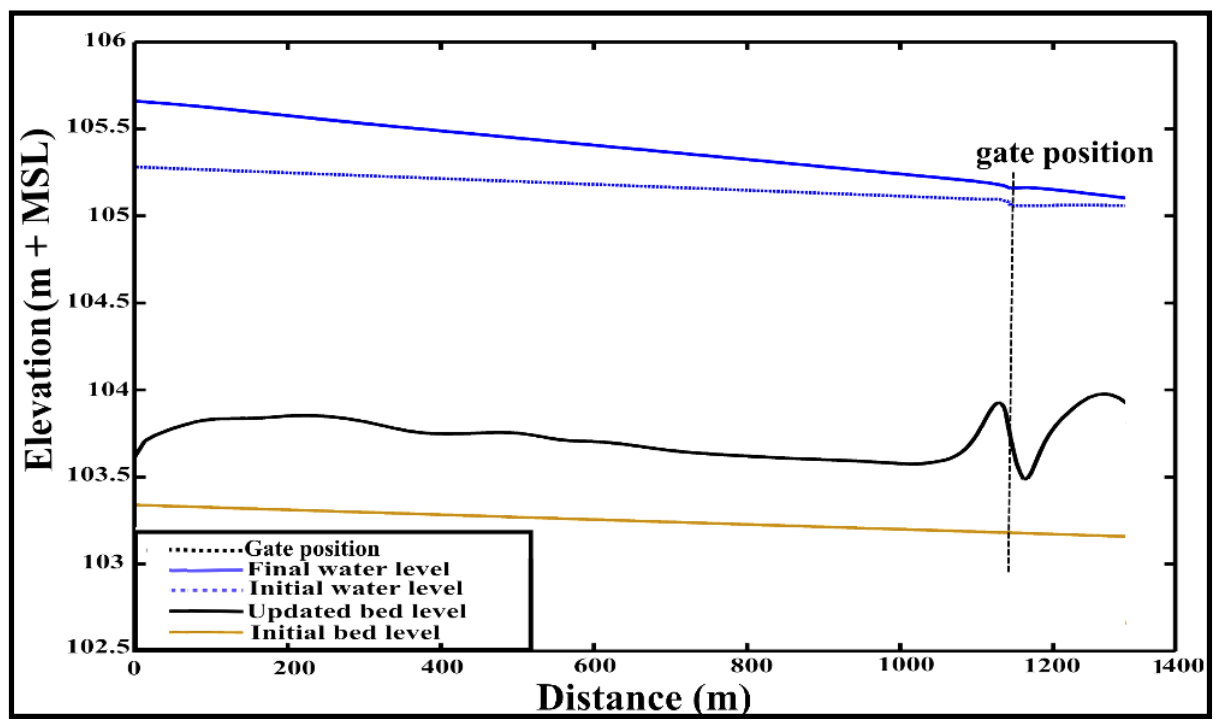

Figure 8. Bed level and water level updating in the main canal without the settling basin.

The velocity reduces along the main canal especially at the location of the diversion, which leads to high sediment deposition (Figure 9). After the diversion, due to the contraction in the main canal at $\mathrm{Km} \mathrm{1.17,} \mathrm{the} \mathrm{velocity} \mathrm{increases} \mathrm{and} \mathrm{the} \mathrm{sediment} \mathrm{deposition} \mathrm{decreases.} \mathrm{After} \mathrm{the} \mathrm{contraction} \mathrm{velocity}$ decreases and sediment accumulation increases (Figure 9). 


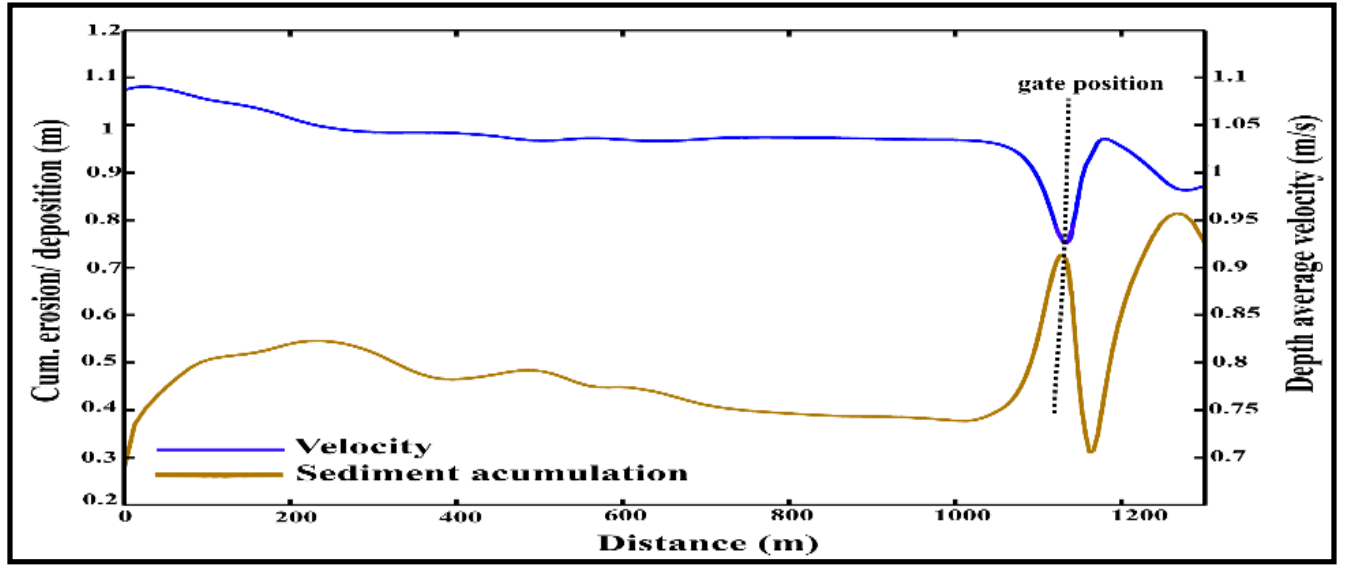

Figure 9. Relationship between velocity and the accumulated sediment in the main canal.

Figure 9 presents a clear relationship between the velocity and the accumulation of sediment. When velocity decreases, the sediment deposition occurs and increases, when the velocity increases, the deposition will be lower.

\subsection{Scenario 2 Gate Operation}

In this scenario, the gates are operated during the simulation period by fully closing and fully opening for a certain time. The simulation consisted of half month during which all gates were fully open, followed by one month during which the gates were fully closed expect the selected gates remain fully open.

\subsubsection{Operating Two Gates}

Gate $a$ and $b$ (SGO2)

The scenario considers opening the gates for a half month, then closing the gates, except for the ones on the right side near the diversion (gate $a$ and gate $b$ in Figure 7) that remain open for an additional month. The sedimentation in this scenario is higher than in the reference case (SGO1) from the beginning of the main canal till the location of gates, where the deposition is much higher (Figure 10). In this scenario, compared to the reference scenario the bed level is higher on the right side and lower on the left side of the canal (Figure 11). Downstream of the gates, the velocity is higher because of closing two gates, causing erosion. Therefore, compared to the reference case, the bed level directly downstream of the gates is lower on the right and left sides and higher in the middle of the canal (Figure 11). In the branch canal, the deposition is slightly less than in the reference case. 

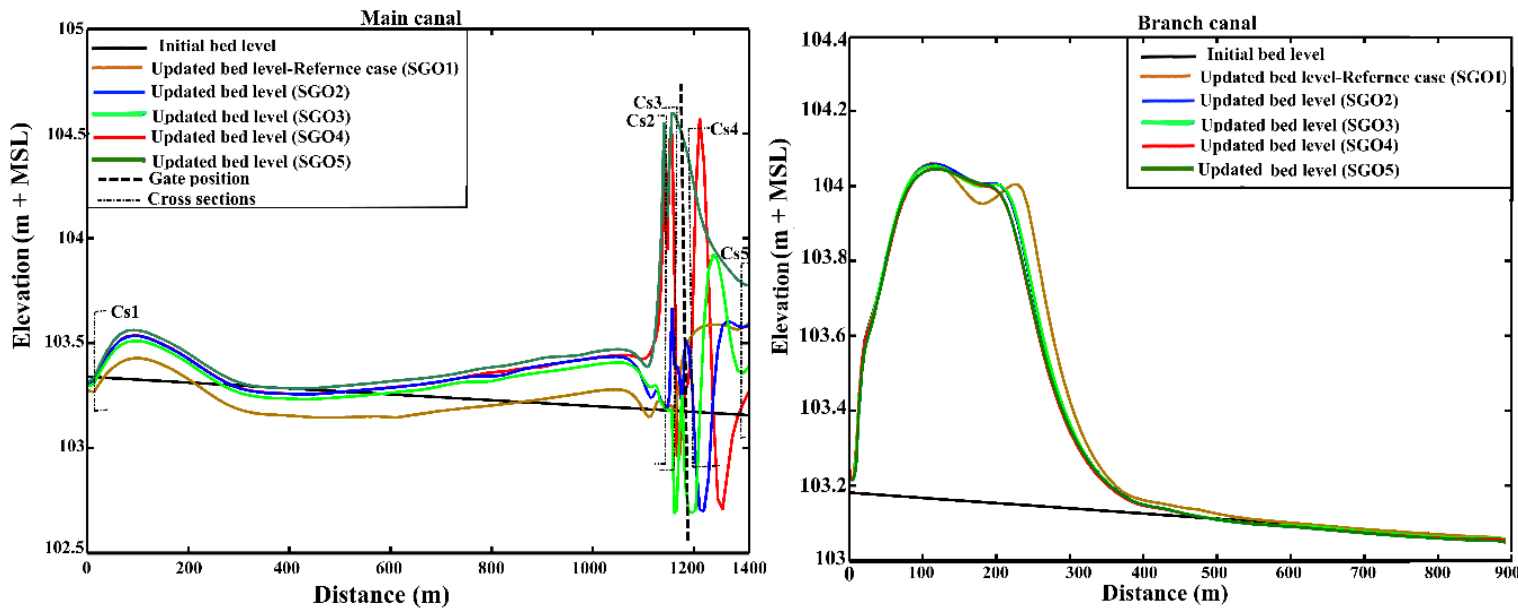

Figure 10. The bed level in scenarios with two gates opened.

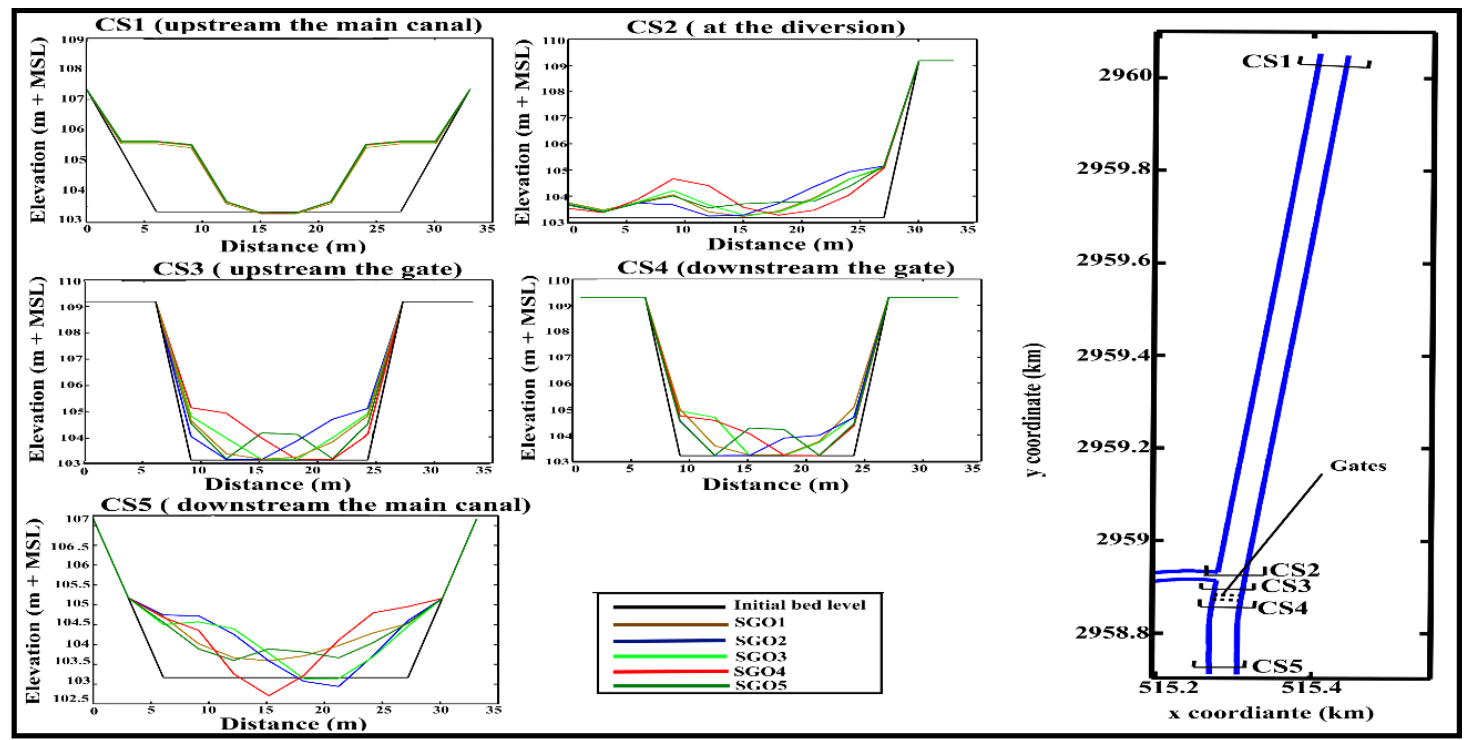

Figure 11. The bed level within different cross-sections in scenarios with two open gates.

Gate $b$ and c (SGO3)

Similar to scenario SGO2, the gates in this scenario are opened for half month; thereafter the gates are closed, except the middle gates (b and c), which stay open for one month. The deposition in this scenario is also higher than the reference case. From the beginning of the main canal till the location of gates, the deposition is much higher (Figure 10) because of the reduction in velocity. The deposition upstream the gates on the right side is higher than in Scenario SGO1 and is lower on the left side, while downstream the gates the opposite occurs (Figure 11). The deposition in scenario SGO3 is lower than in Scenario SGO2.

Gates $c$ and d (SGO4)

Gates $\mathrm{c}$ and $\mathrm{d}$ are opened for one month after closing the other gates. The deposition in this scenario is lower on the right side than the deposition in the previous scenarios, and higher at the left side for the whole main canal (Figure 11) except at the downstream, where the deposition is higher on both sides and erosion occurs in the middle due to the high velocity. Deposition is less because of the high amount of water transferred to the branch canal in this scenario. In the branch canal, the deposition is almost the same with the reference case (Figure 10). 
Gate a and d (SGO5)

Gates a and $\mathrm{d}$ stay open for one month after closing the other gates. The deposition in this scenario is higher than the reference case and SGO4 (Figure 10), and lower than in scenarios SGO2 and SGO3 from the beginning of the main canal till the location of gates, where the deposition is lower in both sides compared to other scenarios and higher in the middle (Figure 11). Downstream in the main canal, the deposition is higher than the reference case (SGO2) and SGO3 but lower than scenarios SGO1 and SGO4.

In these scenarios, opening only two gates from the total number of gates has an actual impact on the sediment transport, flow parameters and the bed of the canal. Figure 10 shows that by using 1D representation, it is hard to tell the difference between the scenarios. However, when presenting the results in cross sections (Figure 11) and plan view (Figure 12) differences between these scenarios can be seen, as well as the position of erosion and accumulation of sediments.

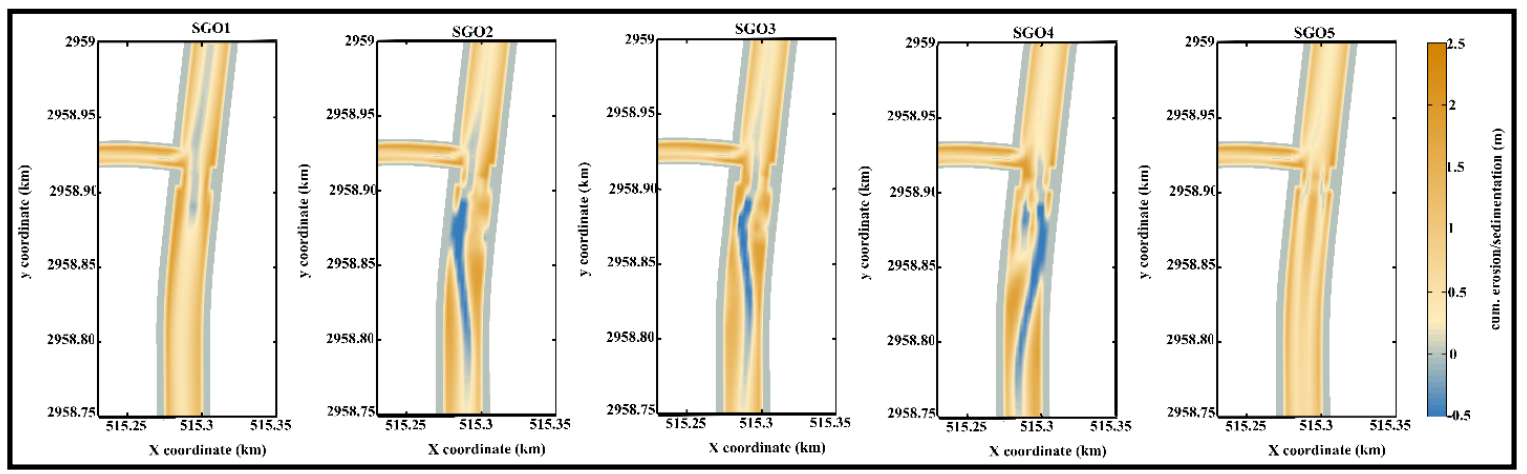

Figure 12. Cumulative erosion/sedimentation by opening two gates compared to the reference case.

The velocity has a major impact on the sediment deposition and erosion patterns along the vicinity of the gate structure in the canal, as discussed previously and shown in Figure 9. The deposition is observable upstream of the gate due to lower velocity, while erosion is visible downstream of the gate due to the higher velocity there. At scenario SGO1 the deposition occurs only on the canal sides due to the lower velocities. However, the deposition is mainly concentrated near the gates that are closed during the simulation.

In scenario SGO2 there is erosion at the left side of the canal and in the middle. In scenario SGO3 erosion occurs in the middle of the canal. In the main canal a significant deposition occurs, especially in the sides where the velocity is low for all scenarios. In scenario SGO4 there is erosion on the right side and in the middle of the canal even attempting to erode the sides of the canal, while sediment is deposited in the region near the diversion due to lower velocities. Furthermore, high sediment deposition before the offtake is observed in this scenario compared to others. In scenario SGO5 there is no erosion, and only deposition in the middle occurs (Figure 12).

\subsubsection{Operating One Gate}

\section{Gate a (SGO6)}

In this scenario, gate a on the side of the diversion is opened for one month after closing all other gates. Deposition in this scenario is higher than deposition in the reference case along the main canal except downstream of the gates until the end of the main canal (Figure 13). In the branch canal, deposition is less than in the reference case, because due to the closing of three gates in the main canal, a large amount of water is diverted to the branch canal, leading to an increased transport capacity and reduced deposition from the start of the branch canal up to $400 \mathrm{~m}$ (Figure 13). After $400 \mathrm{~m}$ to the end of the branch canal, erosion will occur due to the increase in the velocity. Within the cross-section the deposition downstream the gate and in the middle of the branch canal for case SGO6 is lower on 
both sides than the reference case, and is equal in the middle while downstream the branch canal the deposition is few millimeters higher on both sides than the reference case, small erosion in the middle of the cross-section (Figure 14).
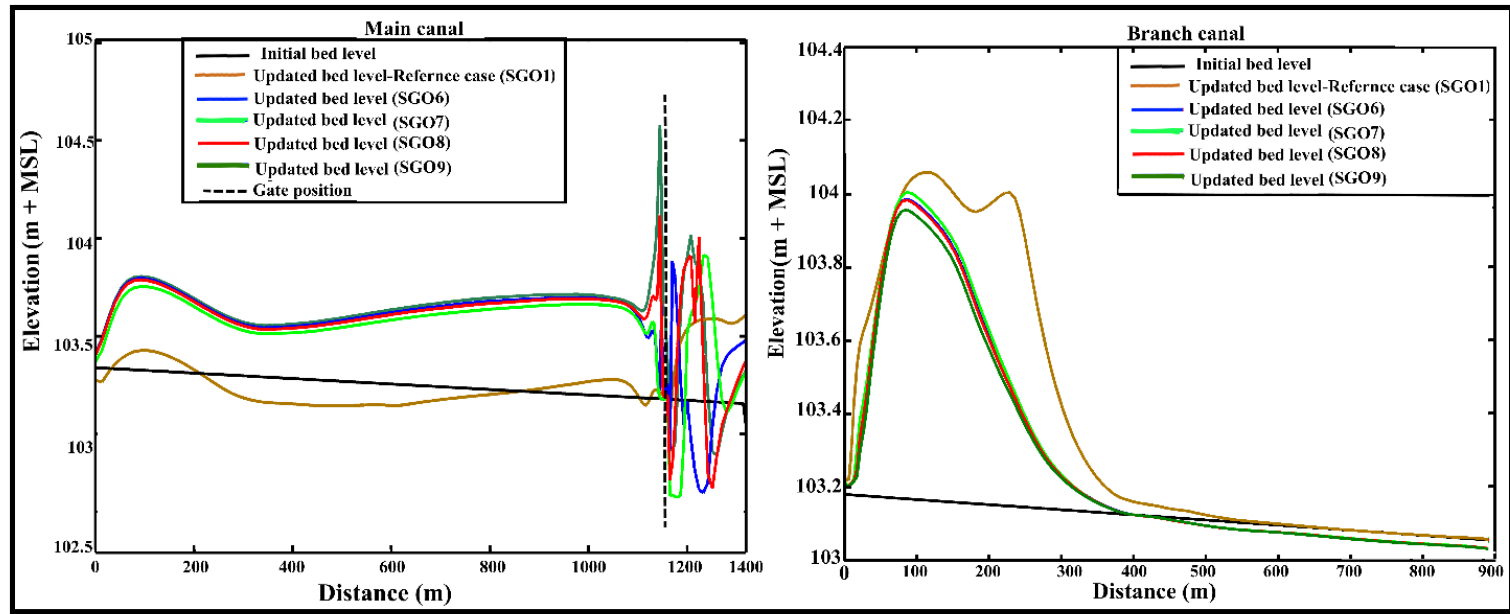

Figure 13. The bed level in scenarios with one gate opened.

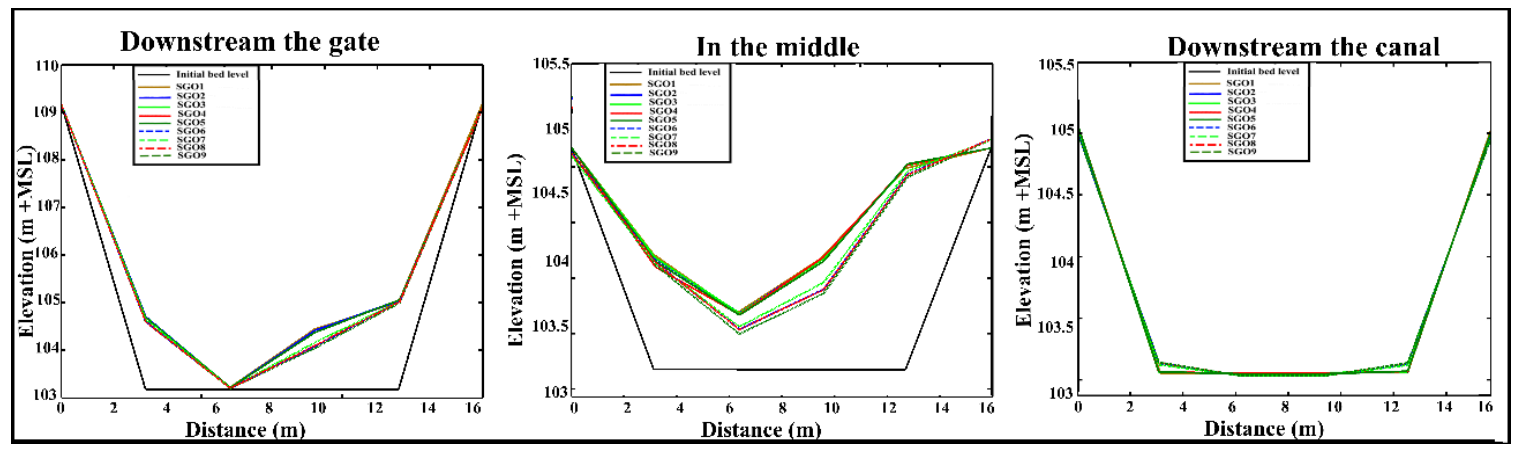

Figure 14. The bed level within cross-section in different scenarios.

Gate b (SGO7)

Gate $b$ is opened for one month after closing all other gates. Deposition is similar as in scenario SGO6 in the main canal, branch canal and in the cross-sections (Figures 13 and 14).

Gate c (SGO8)

Gate $\mathrm{c}$ is opened for one month after closing all other gates. The deposition is similar to SGO6 and SGO7 (Figures 13 and 14).

Gate d (SGO9)

Gate $\mathrm{d}$, on the other side from the diversion side, is opened for one month, after closing all other gates. The deposition is similar to SGO6, SGO7 and SGO8 (Figures 13 and 14).

Figure 14 shows that the effect of opening one gate on sedimentation is different from that of opening two gates. Opening one gate provides less deposition downstream of the gate compared to the deposition in the reference case and in the case of opening two gates. Additionally, opening one gate produces less deposition in the middle of the branch canal on both sides than opening two gates and the reference case.

Opening gate a only leads to small sediment deposition upstream part the branch canal as compared to scenarios SGO7, SGO8 and SGO9. In the main canal, downstream of the gate, deposition occurs 
at the side far from the diversion and erosion occurs at the side close to the diversion due to high velocity. Thereafter, erosion exists in the middle of the canal while deposition occurs at both sides of the bed due to low velocities (Figure 15). Opening gate $b$ leads to erosion in the middle of the main canal, which moves to the side far from the diversion. Opening gate c in scenario SGO8 leads to more deposition upstream of the branch canal and deposition upstream the gate. Downstream of the gate, erosion exists in the side far from the diversion due to the high velocity and in the middle thereafter and deposition in both sides. Opening gate (d) has similar deposition and erosion patterns as the opening of gate $\mathrm{c}$ but with more erosion.

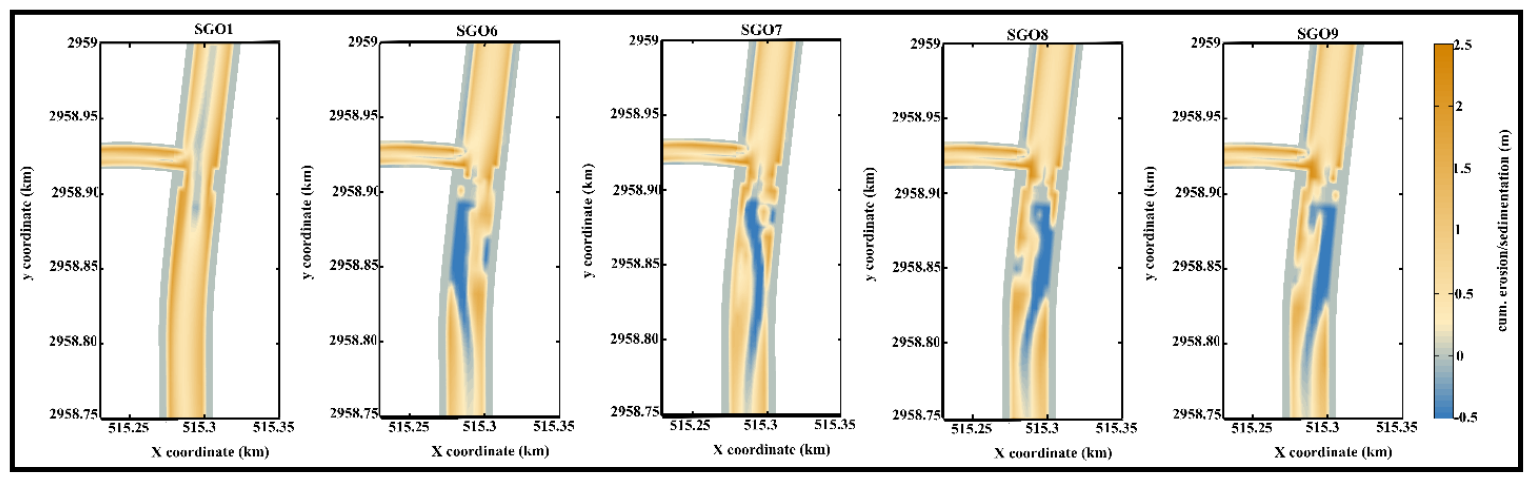

Figure 15. Cumulative erosion/sedimentation by opening one gate compared to the reference case.

Since purely 1D models cannot predict lateral variations in erosion rates, the results in Figures 14 and 15 are a benefit of using multi-dimensional models to represent the difference in bed level within the cross-section under different scenarios. Knowing these differences can help decision-makers to choose the optimal canal operation by selecting the suitable gate to minimize deposition, while at the same time ensuring the required amount of water for crops is delivered. From these two scenarios. Opening only one gate from the total number of gates has a greater influence on the sediment transport, flow criteria and the morphology for the canal bed than opening two gates.

\section{Discussion}

The basic function of the regulating structures is to convey the required amount of water to where it is needed, for example to the offtakes to the branch canals, and maintain a certain water level there. The reference scenario (SGO1) with all gates open diverts $29 \%$ of water to the branch canal. As expected, after closing two or three gates in the regulator, more water enters the branch canal at the first time-steps. Scenarios with two open gates divert 7\% to $8 \%$ more water to the branch canal as compared to the reference case. Scenarios with one open gate, divert about $19 \%$ to $21 \%$ more water to the branch canal as compared to the reference case (Table 5).

Table 5. Percentage of diverted discharge to the main and branch canals.

\begin{tabular}{cccccccccc}
\hline \% of Discharge Diverted & SGO1 & SGO2 & SGO3 & SGO4 & SGO5 & SGO6 & SGO7 & SGO8 & SGO9 \\
\hline Main Canal & 71 & 64 & 64 & 63 & 63 & 51 & 52 & 52 & 50 \\
Branch Canal & 29 & 36 & 36 & 37 & 37 & 49 & 48 & 48 & 50 \\
\hline
\end{tabular}

Scenario SGO5 diverts less water than scenarios SGO2, SGO3 and similarly SGO4 because in this scenario gates a and $\mathrm{d}$ are open, which are at the sides of the main canal where the flow velocity is less than in the middle because of wall friction. Opening gate $b$ or c located in the middle of the main canal (scenarios SGO7 and SGO8, respectively), results in less water diverted to the branch canal than in scenarios SGO6 and SGO9. 
Comparing the different gate operation scenarios with one or two gates open, it is clear that not only the number but also the location of the selected gate(s) has an impact on sediment deposition. Opening the gate which is at the side of the offtake leads to less sediment deposition at the upstream of the regulating gates (Table 6). Opening the farther gate leads to higher sediment deposition at the intake. This deposition will not only alter the hydrodynamic characteristics but also morphologic characteristics of the canal, which can result in system inefficiencies as regulating gates are of crucial importance. The sediment depositions around structures are harder to remove and manage.

Table 6. Percentage of sediment diverted and stored at the main and branch canals for different scenarios.

\begin{tabular}{|c|c|c|c|c|c|c|c|c|c|}
\hline \multicolumn{10}{|c|}{ At the Main Canal } \\
\hline$\%$ of sediment & SGO1 & SGO2 & SGO3 & SGO4 & SGO5 & SGO6 & SGO7 & SGO8 & SGO9 \\
\hline $\begin{array}{l}\text { Deposited along the main } \\
\text { canal before the diversion }\end{array}$ & 79 & 81 & 80 & 80 & 81 & 84 & 84 & 84 & 84 \\
\hline Diverted to branch canal & 6 & 8 & 8 & 7 & 8 & 7 & 8 & 8 & 7 \\
\hline Stored at $\mathrm{u} / \mathrm{s}$ of the gate & 2 & 0 & 0 & 0 & 0 & 0 & 0 & 0 & 0 \\
\hline $\begin{array}{l}\text { Deposited along the main } \\
\text { canal } \mathrm{d} / \mathrm{s} \text { the diversion }\end{array}$ & 14 & 12 & 12 & 13 & 11 & 9 & 8 & 8 & 9 \\
\hline Total \% & 100 & 100 & 100 & 100 & 100 & 100 & 100 & 100 & 100 \\
\hline \multicolumn{10}{|c|}{ At the branch canal } \\
\hline Deposited at branch canal & 78 & 94 & 95 & 94 & 94 & 92 & 92 & 93 & 93 \\
\hline $\begin{array}{l}\text { Transported out of the } \\
\text { branch canal }\end{array}$ & 22 & 6 & 5 & 6 & 6 & 8 & 8 & 7 & 7 \\
\hline Total \% & 100 & 100 & 100 & 100 & 100 & 100 & 100 & 100 & 100 \\
\hline
\end{tabular}

The results in Table 6 show that when one gate is opened, the amount of deposited sediments in the upstream part of the main canal is higher than in scenarios with two open gates and the reference case, because in the latter scenarios more water, and hence more sediments, flow towards downstream of the main canal. Opening gates at the diversion side convert more water and sediments to downstream of main canal than when opening gates at the opposite side. Gates on the opposite side leads to having less sediment transport capacity and consequently higher deposition which is transported to the branch. The sediment stored at the branch canal is around $2 \%$ in the reference scenario while a negligible amount is stored in the other scenarios.

Among the scenarios with one open gate, the location of the gate has a small impact on the amount of sediment diverted to the branch canal. In scenarios SGO6 and SGO9 the sediment is slightly less compared to other scenarios. Although the difference is small, it is worth mentioning that gate operation does have an impact on the sedimentation and erosion of the branch canal.

Additionally, in scenarios of two open gates, the amount of water transferred to the branch canal in the case of SGO4 is more than the reference case, SGO2 and SGO3 and similar to SGO5 as shown in Table 5. On the other hand, the amount of sediment transferred to the branch canal in the case of SGO4 is less than other scenarios of two open gates, as shown in Table 6.

In scenarios of one gate open, the amount of water transferred to the branch canal in the case of SGO9 is more than other scenarios as shown in Table 5. On the other hand, the amount of sediment transferred to the branch canal in the case of SGO9 is less than SGO7, SGO8 and similar to SGO6 as shown in Table 6.

In practice, usually, it is preferred for gate operations to have less effect on the canal shape, in this case, the operation of the gate SGO4 seems a better choice among the scenarios with two open gates. The operation of the gate SGO9 seems a better choice among the scenarios with one open gate. This has ensured delivering a higher amount of water to the branch canal with fewer sediments.

A slight change in hydrodynamic characteristics changes the sediment transport mechanism and thus the canal morphology, which in turn changes the water flow features in the canal [3]. The results show that because of gate operation the change in the flow characteristics alters the amount of sediment 
passing through each cross-section different for each scenario. This means that gate operation has a significant effect on the hydrodynamic as well as the morphologic parameters in an irrigation system [3]. Gate operation can be used as not only the as diverting the water but also as a sediment management technique. The incoming flow through time can erode the accumulated sediment and flush it away. This is because of the change in the canal properties and the hydraulics of the canal. For this reason, it can be said that there is constant sediment erosion and deposition until the equilibrium state is reached, which can occur only in the case of non-cohesive sediments.

Operating the gate at the side of the offtake can minimize the sediment deposition at the entrance of the offtake; however, if the same gates are regularly opened, the canal geometry will be permanently altered due to the deposition and erosion resulted from this gate operation, which is not appropriate for equitable water distribution and for the proper system functioning. Additionally, the deposited sediments during one gate operation can be removed during the other [16].

The results from comparison of the scenarios show that the number of gates opened as well as their location has an impact on sedimentation and erosion patterns in the both the main and branch canal. Not only the amount of sediment deposition but also the location in the cross section of the canal depends on the gate selection. Therefore, a canal operation plan along with the gate operation schedules can help to increase the canal efficiency and to reduce sediment removal costs. Alternating the gates to be opened during the irrigation period can help to reduce the sediments around the flow control structures, while at the same time delivering sufficient water to the branch canals. Sediment depositions can be eroded with the help of the canal operation itself, by alternating the gate to be opened, without investing extra money and labor for the cleaning process.

This paper considers non-cohesive sediments only. In reality, many irrigation systems take water from rivers which contain a mix of cohesive and non-cohesive sediments. This shall be considered in future research.

\section{Conclusions}

The study confirms that gate operations have a significant impact on the overall hydrodynamic and morphologic behavior of the irrigation system [43]. The simulations using a multi-dimensional numerical showed that opening the gate on the side of offtake resulted in less deposition of sediment at the entrance of the offtake than when the gate on the other side of the offtake was opened. This means that the selection of gates to be opened for delivering a certain amount of water has a major impact on the spatial sediment erosion and deposition patterns, and it shows the benefit of using such multi-dimensional simulation models. An analysis using merely a 1D model, as has been the de facto standard until this date, would have missed such asymmetric channel developments.

Furthermore, the simulations showed that the gate selection did not only impact the main canal, but it also extended to the branch canal. Although a primarily one-dimensional morphological response was observed both upstream and downstream of the closed gates, those erosion and deposition patterns include a secondary asymmetric distribution along the canal and within the cross-section. Again, this supports the need for using multi-dimensional models for such situations in order to obtain a better estimate of the maintenance costs under various scenarios. While 1D models provide insight in the mean depositional pattern in the longitudinal direction of irrigation canals, asymmetric deposition patterns can only be resolved by including the second spatial dimension in the simulation.

All simulations reported in this paper were carried out in both depth-averaged (2D) and 3D hydrostatic mode using five layers. While the 3D mode provides a slightly better description of the physics involved, the running times are quite long for large irrigation canal networks. Compared to 1D models, the use of Delft3D run in 2D mode has a clear benefit by providing an estimate of the asymmetric development of the hydraulics and morphology, while avoiding the long simulation times of 3D models [43]. However, for the simulations considered here the extra simulation time of the 3D models has not shown a significant benefit for this type of application. 
Supplementary Materials: The following are available online at http://www.mdpi.com/2073-4441/12/10/ 2765/s1. Other helpful scenarios results are available online at: https://drive.google.com/open?id= 1OJcf0Oueq1ZDENKaSWitifs0riPvR1HQ.

Author Contributions: S.T. carried out this research, conceived ideas and wrote the paper and revised it. B.J. took part in the implementation, analysis, guiding of the ideas. J.R.Y. participated in writing the first draft of the paper and in constructing the grid for the case study. F.X.S. participated in guiding the ideas. C.d.F. supervised and took part in the implementation, analysis, guiding the ideas and in the revising process. All authors have read and agreed to the published version of the manuscript.

Funding: This research received no external funding.

Acknowledgments: The authors show their appreciation K.P. Paudel and SMIS for their field data and reports that have other data helpful for this research. The technical support from Deltares is really appreciated, especially Edward Melger.

Conflicts of Interest: The authors declare no conflict of interest.

\section{References}

1. Depeweg, H.; Paudel, K.P.; Méndez, N. Sediment Transport in Irrigation Canals: A New Approach; CRC Press/Balkema: Leiden, The Netherlands, 2014.

2. Osman, I.S.; Schultz, B.; Osman, A.; Suryadi, F. Simulation of fine sediment transport in irrigation canals of the gezira scheme with the numerical model FSEDT. J. Irrig. Drain. Eng. 2016, 142. [CrossRef]

3. Munir, S. Role of Sediment Transport in Operation and Maintenance of Supply and Demand Based Irrigation Canals: Application to Machai Maira Branch Canals: UNESCO-IHE; CRC Press/Balkema: Leiden, The Netherlands, 2011.

4. Dal Sasso, S.F.; Sole, A.; Pinzón, A.B.; Medina, V.; Mirauda, D.; Plantamura, A.V.; Giosa, L.; Guariglia, A. Analysis of river bed dynamic evolution following a landslide dam. La Houille Blanche 2015, 88-95. [CrossRef]

5. Shimizu, Y.; Nelson, J.; Arnez Ferrel, K.; Asahi, K.; Giri, S.; Inoue, T.; Iwasaki, T.; Jang, C.L.; Kang, T.; Kimura, I. Advances in computational morphodynamics using the International River Interface Cooperative (iRIC) software. Earth Surf. Process. Landf. 2020, 45, 11-37. [CrossRef]

6. Depeweg, H.; Paudel, K. Sediment transport problems in Nepal evaluated by the SETRIC model. Irrig. Drain. 2003, 52, 247-260. [CrossRef]

7. Paudel, K.P. Role of Sediment in the Design and Management of Irrigation Canals: Sunsari Morang Irrigation Scheme, Nepal: UNESCO-IHE; CRC Press/Balkema: Leiden, The Netherlands, 2010.

8. Theol, S.; Jagers, B.; Suryadi, F.; De Fraiture, C. The role of operation in reducing problems with cohesive and non-cohesive sediments in irrigation canals. Water 2019, 11, 2572. [CrossRef]

9. Theol, S.; Jagers, B.; Suryadi, F.; De Fraiture, C. The use of 2D/3D models to show the differences between cohesive and non-cohesive sediments in irrigation systems. Am. J. Irrig. Drain. Eng. (ASCE) 2020. forthcoming.

10. Acuña, G.J.; Ávila, H.; Canales, F.A. River model calibration based on design of experiments theory. A case study: Meta River, Colombia. Water 2019, 11, 1382. [CrossRef]

11. Berchtold, T.; Weitbrecht, V.; Vetsch, D.; BOES, R. Numerical modelling of bed level evolution in a channel enlargement. In Proceedings of the RCEM 2011: Proceedings of the 7th IAHR Symposium of River, Coastal and Estuarine Morphodynamics, Beijing, China, 6-8 September 2011; pp. 1425-1435.

12. Roelvink, D.; Reniers, A.; Van Dongeren, A.; De Vries, J.V.T.; McCall, R.; Lescinski, J. Modelling storm impacts on beaches, dunes and barrier islands. Coast. Eng. 2009, 56, 1133-1152. [CrossRef]

13. Villaret, C.; Hervouet, J.-M.; Kopmann, R.; Merkel, U.; Davies, A.G. Morphodynamic modeling using the Telemac finite-element system. Comput. Geosci. 2013, 53, 105-113. [CrossRef]

14. Deltares. Delft3D-Flow User Manual; Deltares: Delft, The Netherlands. Available online: https://oss.deltares. nl/documents/183920/185723/Delft3D-FLOW_User_Manual.pdf (accessed on 17 September 2020).

15. Lesser, G.R.; Roelvink, J.v.; Van Kester, J.; Stelling, G. Development and validation of a three-dimensional morphological model. Coast. Eng. 2004, 51, 883-915. [CrossRef]

16. Yangkhurung, J.R. Effect of Canal Operation on Sedimentation and Erosion in Irrigation Canals: A Case Study in Sunsari Morang Irrigation System, Nepal; UNESCO-IHE: Delft, The Netherlands, 2018.

17. Mishra, S.K. Draft Report On Main Irrigation Canal Operation Plan For Crops In Sitagunj Secondary Canal (S9) Irrigation System; Department of Irrigation-IWRMP: Katmandu, Nepal, 2016. 
18. Department of Irrigation. Design Report Vol-I, Main Report and Appendices; Prepared by NEDECO for Sunsari Morang Irrigation Project Stage III (Phase-I), Department of Irrigation, Ministry of Water Resources: Katmandu, Nepal, 2003.

19. Chow, T.V. Open-Channel Hydraulics; McGraw-Hill: New York, NY, USA, 1959; Volume 1.

20. Renault, D.; Wahaj, R. MASSCOT: A Methodology to Modernize Irrigation Services and Operation in Canal Systems. Applications to Two Systems in Nepal Terai: Sunsari Morang Irrigation System and Narayani Irrigation System; FAO: Rome, Italy, 2006; pp. 1-42.

21. Javernick, L.; Hicks, D.; Measures, R.; Caruso, B.; Brasington, J. Numerical modelling of braided rivers with structure-from-motion-derived terrain models. River Res. Appl. 2016, 32, 1071-1081. [CrossRef]

22. Flokstra, C. Modelling of submerged vanes. J. Hydraul. Res. 2006, 44, 591-602. [CrossRef]

23. Parsapour-Moghaddam, P.; Rennie, C.D. Hydrostatic versus nonhydrostatic hydrodynamic modelling of secondary flow in a tortuously meandering river: Application of Delft3D. River Res. Appl. 2017, 33, 1400-1410. [CrossRef]

24. Lesser, G.R. An Approach to Medium-Term Coastal Morphological Modelling: UNESCO-IHE; CRC Press/ Balkema: Leiden, The Netherlands, 2009; p. 255.

25. Roelvink, J.; Van Banning, G. Design and development of DELFT3D and application to coastal morphodynamics. Oceanogr. Lit. Rev. 1995, 11, 925.

26. Elias, E.; Walstra, D.; Roelvink, J.; Stive, M.; Klein, M. Hydrodynamic validation of Delft3D with field measurements at Egmond. In Proceedings of the 27th International Conference on Coastal Engineering (ICCE), Sydney, Australia, 16-21 July 2000; pp. 2714-2727.

27. Van der Wegen, M.; Jaffe, B.; Roelvink, J. Process-based, morphodynamic hindcast of decadal deposition patterns in San Pablo Bay, California. J. Geophys. Res. Earth Surf. 2011, 116, 1856-1887. [CrossRef]

28. Gebrehiwot, K.A.; Haile, A.M.; De Fraiture, C.; Chukalla, A.D.; Tesfa-alem, G.E. Optimizing flood and sediment management of spate irrigation in Aba'ala Plains. Water Resour. Manag. 2015, 29, 833-847. [CrossRef]

29. Theol, A.S.; Jagers, B.; Suryadi, F.; de Fraiture, C. The use of Delft3D for irrigation systems simulations. Irrig. Drain. 2019, 68, 318-331. [CrossRef]

30. De St Venant, B. Theorie du mouvement non-permanent des eaux avec application aux crues des rivers et a l'introduntion des Marees dans leur lit. Acad. de Sci. Comptes Redus 1871, 73, 148-154.

31. De SAINT-VENANT, B. AJC (1871b). Théorie et Equations Générales du Mouvement Non Permanent des Eaux, avec Application aux Crues des Rivières et à l'Introduction des Marées dans leur Lit (2ème Note). Comptes Rendus des Séances de l'Académie des Sci. 1871, 73, 237-240.

32. Phillips, N.A. A coordinate system having some special advantages for numerical forecasting. J. Meteorol. 1957, 14, 184-185. [CrossRef]

33. Stelling, G.S.; Leendertse, J.J. Approximation of convective processes by cyclic AOI methods. In Proceedings of the Estuarine and Coastal Modeling, Tampa, FL, USA, 13-15 November 1992; pp. 771-782.

34. Postma, L.; Stelling, G.S.; Boon, J. 3-dimensional water quality and hydrodynamic modelling in Hong Kong III. Stratification and water quality. In Proceedings of the Second International Symposium on Environmental Hydraulics, Hong Kong, China, 16-18 December 1998; Lee, J.H.W., Jayawardena, Q.W., Wang, Z.Y., Eds.; Balkema: Rotterdam, The Netherlands, 1999; pp. 43-49.

35. Rozovski1̆, I.L.V. Flow of Water in Bends of Open Channels; Academy of Sciences of the Ukrainian SSR: Kiev, Ukraine, 1957.

36. Stelling, G.S.; Van Kester, J.A.T.M. On the approximation of horizontal gradients in sigma co-ordinates for bathymetry with steep bottom slopes. Int. J. Numer. Methods Fluids 1994, 18, 915-935. [CrossRef]

37. Van Rijn, L.C. Principles of Sediment Transport in Rivers, Estuaries and Coastal Seas; Aqua Publications: Amsterdam, The Netherlands, 1993.

38. Soulsby, R. Dynamics of Marine Sands: A Manual for Practical Applications; Thomas Telford: London, UK, 1997.

39. De Goede, E.D. Historical overview of 2D and 3D hydrodynamic modelling of shallow water flows in the Netherlands. Ocean Dyn. 2020, 70, 521-539. [CrossRef]

40. Nippon, K. Project Operation Plan; Sunsari Morang Irrigation Project; Ministry of Water Resources, Singhdurbar: Kathmandu, Nepal, 1995.

41. Devkota, L.; Crosato, A.; Giri, S. Effect of the barrage and embankments on flooding and channel avulsion case study Koshi River, Nepal. Rural Infrastruct. 2012, 3, 124-132. 
42. DFID, M.M. Equity, Irrigation and Poverty, Guidelines for Sustainable Water Management; Cambridge CB1 2RS UK: Final Report; 2006. Available online: https://assets.publishing.service.gov. uk/media/57a08c17ed915d3cfd001172/R8338EIP_Final_Report_Appendices_Jan2007.pdf (accessed on 20 September 2020).

43. Theol, S.A.A.-A. The Use of Delft3D to Simulate the Deposition of Cohesive and Non-Cohesive Sediments in Irrigation Systems; CRC Press: Boca Raton, FL, USA, 2020.

(c)

(C) 2020 by the authors. Licensee MDPI, Basel, Switzerland. This article is an open access article distributed under the terms and conditions of the Creative Commons Attribution (CC BY) license (http://creativecommons.org/licenses/by/4.0/). 